in Prague, the problems of the Danubian basin with special attention to the peaceful collaboration of peoples inhabiting it, in the new Europe which must arise from the present cataclysm".

The Central European Observer was always well informed on scientific as well as other matters, and gave readable accounts of archæological, biological, chemical, physical and other scientific discoveries and advances made in Central Europe, and its industrial sections frequently referred to new technical applications of scientific knowledge. The first issue of the new series, which retains most of the features of the former Central European Observer, contains an article by the late Karel Capek entitled "The Death of Archimedes".

\section{American University Education}

A DeCEMber number of School and Society opens with "Statistics of Registration in American Universities and Colleges, 1939", a remarkable survey by the president of the University of Cincinnati. No fewer than 648 institutions are noticed with various comments in detail, and one realizes the vast attendance in a population, perhaps, four times as big as that of Great Britain. The figures, 873,697 full-time students, and with part-time and summer schools, 1,323,874, show an advance on 1938. The United States spends more of its holidays in learning than Great Britain does, though some of the instruction provided and degrees awarded do not reach the British level of attainment. The south-central divisions of East and West and teachers' colleges and technological institutions show the largest increase. In the Freshman Table the trend of the time appears in the 34 per cent additions to engineering, and we are glad to see a distinct though lesser gain in liberal arts. The establishment of a Graduate School of Education at Los Angeles may in time modify the crudities of American films and scenario writers.

\section{Whales}

UNDER the title of "Whales, Giants of the Sea", Mr. R. Kellogg contributes to the National Geographic Magazine of January a long article on whales and whaling which is specially noteworthy for the detailed notes on the size, appearance, distribution and habits of more than thirty species of cetaceans and coloured illustrations of nearly every species. Each illustration depicts the whale at sea, often feeding, sometimes in contact with its enemy and frequently in schools. These pictures probably constitute a unique gallery and are of considerable value.

\section{Society for the Bibliography of Natural History}

AT the annual general meeting of the Society for the Bibliography of Natural History held on February 3 , the following officers for 1940 were elected : President, Dr. C. Davies Sherborn; Treasurer, Mr. Francis Hemming; Secretary, Mr. Francis J. Griffin. The Treasurer's report indicated that the Society's financial position is strong; but the need for new members was stressed if the Society is to continue its activities on the present scale. It was reported that a fund has been set up for the publication of facsimiles of rare works, and the president, Dr. C. Davies Sherborn, has started the fund with a handsome donation.

\section{Aftershocks of the Earthquake in Turkey}

These still continue in considerable numbers and some reach a high intensity. In the Erzinjan area the two villages of Besin and Pulur were destroyed by a shock which killed forty-five people and injured many more on February 3. On February 4, tremors were felt at Ankara, Sivas and Zara, and a village was destroyed, killing ten people and seriously injuring three others.

\section{The Colonial Service: Recent Appointments}

THE following appointments and promotions have recently been made in the Colonial Service: $M$. Halcrow, agricultural officer, Kenya, agricultural officer, St. Helena; T. D. Marsh, agriculturist, senior agriculturist, Malaya; F. R. Mason, deputy director of agriculture and fisheries, director of agriculture and fisheries, Palestine; R. Smeathers, assistant conservator, Tanganyika Territory, assistant conservator, Trinidad; T. G. Wood, senior assistant conservator, conservator, Nigeria; R. Coulthard, veterinary officer, senior veterinary officer, Nigeria; R. M. Gambles, veterinary research officer, Palestine, veterinary officer, Cyprus; D. R. R. Burt, lecturer and head of Department of Zoology, professor of zoology, University College, Ceylon.

\section{Announcements}

THe Harben Gold Medal for 1940 of the Royal Institute of Public Health and Hygiene has been awarded to Sir Leonard Hill, formerly professor of physiology in the University of London. The Smith Award for 1940 has been conferred on Sir William Savage, formerly medical officer of health, Somerset.

AT a meeting of the Royal Astronomical Society held on February 9, the following officers were elected for 1940-41 : President, Prof. H. C. Plummer ; VicePresidents, Prof. David Brunt, Prof. Alfred Fowler, Dr. H. Spencer Jones, Sir James Jeans ; Treasurer, Mr. J. H. Reynolds; Secretaries, Dr. R. d'E. Atkinson, Mr. D. H. Sadler; Foreign Secretary, Sir Arthur Eddington.

The annual prize awarded by the Royal Asiatic Society for its universities prize essay has been awarded this year to Mr. Asa Briggs, of Sidney Sussex College, Cambridge. Of the subjects offered, Mr. Briggs wrote on "The Influence of Sea Power on the History of the East India Company".

THE Sixth International Congress for Experimental Cytology, which had been arranged to take place in Stockholm during July 25-August 1, 1940, has, on account of the international situation, been postponed indefinitely.

Prof. Bidhan Chunder Roy, of Calcutta, has been elected president of the Medical Council of India in succession to Major-General E. W. C. Bradfield. Prof. Roy is the first non-official president and the first Indian to hold the office. 